МИРОНЕНКО Т. С., кандидат юридичних наук, доцент кафедри правосуддя (Сумський національний аграрний університет)

\title{
РОЛЬ ПРОКУРОРА У ВІДІБРАННІ ЗРАЗКІВ ДЛЯ ПРОВЕДЕННЯ СУДОВОЇ ЕКСПЕРТИЗИ
}

У статті проаналізовано актуальні проблеми, що стосуються відбору біологічних зразків у підозрюваного (обвинуваченого, підсудного), механізм здійснення такого відбору, а також надані варіанти дій у разі здійснення примусового відбору біологічного матеріалу. Автор зосередив увагу на ролі прокурора в процесі виконання ухвали суду про відібрання зразків для призначення судової експертизи, а також висвітлив проблеми, з цим пов'язані. Саме поняття біологічних зразків у вітчизняному законодавстві відсутнє, тому автор зробив спробу визначення як поняття, так і механізму опрацювання біологічних зразків в процесі їх вилучення у примусовий спосіб. Біологічними зразками, на думку автора статті, слід вважати продукти виділення людини, серед яких слина, кров, сперма, вагінальні виділення, потожирова речовина, волосся, відлущення шкірного покриву. Все інше слід відносити до об'єктів біологічного походження. В статті також визначене коло суб’єктів, які уповноважені здійснювати відбирання зразків. Добровільне відбирання зразків для проведення експертизи здійснюється як процесуальна дія, результати якої оформлюються у протокольній формі слідчим (або прокурором). До участі в дії може бути залучено спеціаліста, понятих, захисника. Присутність інших учасників здійснюється за їх клопотанням і його задоволенням. Порядок відібрання зразків $з$ речей і документів зумовлюється положеннями про тимчасовий доступ до речей і документів. Також зразки можуть вилучатись за допомогою таких слідчих (розшукових) дій, як обшук, освідування, а також безпосередньо примусового відбору. На відміну від добровільного відбирання зразків, примусове може тягнути за собою низку негативних наслідків через те, що механізм такого відбору в кодексі не прописаний. Автором запропоновано в кожному випадку кримінального провадження обирати свій спосіб, який би найбільш продуктивно забезпечував виконання завдань кримінального провадження в частині повного, швидкого і неупередженого розслідування.

Ключові слова: біологічні зразки, клопотання, примусовий відбір, прокурор, процесуальна дія, спеціаліст, судова експертиза.

The article analyzes the actual problems related to the selection of biological samples from the suspect (accused, defendant), the mechanism of such selection, as well as options for actions in the case of forced selection of biological material. The author focused on the role of the prosecutor in the enforcement of the court decision on the selection of samples for the purpose of forensic examination, and highlighted the problems associated with this. The very concept of biological specimens is absent in the domestic legislation, so the author made an attempt to define as a concept and mechanism of processing biological specimens during their

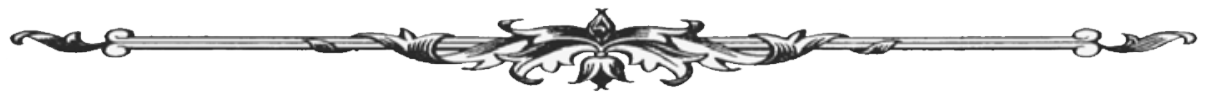


removal in a forced way. Biological specimens, according to the author of the article, should be considered products of human excretion, including saliva, blood, semen, vaginal discharge, urinary substance, hair, exfoliation of the skin. Everything else should be attributed to objects of biological origin. The article also identifies a range of entities that are authorized to sample. Voluntary sampling for examination is carried out as a procedural action, the results of which are formalized in the protocol form by the investigator (or prosecutor). A specialist, an expert witness and a defense lawyer may be involved in the action. The presence of other participants is carried out at their request and at his pleasure. The order of sampling of things and documents is determined by the provisions on temporary access to things and documents. Samples may also be removed by means of investigative (search) actions such as searches, searches, and direct enforcement. Unlike voluntary sampling, compulsory sampling can entail a number of negative consequences because the mechanism of such sampling is not spelled out in the code. The author proposes in each case of criminal proceedings to choose his own method, which would most effectively ensure the execution of the tasks of criminal proceedings in the part of a full, prompt and impartial investigation.

Key words: biological samples, petition, forced selection, prosecutor, procedural action, specialist, forensic examination.

Вступ. Одним із найбільш спірних питань, серед інших процесуальних дій, є примусове відбирання біологічних зразків у особи і роль прокурора в цій процесуальній дії. Питання примусового відбирання постає у разі, якщо підозрюваний (обвинувачений, підсудний) не бажають надати такі зразки у добровільному порядку [1, ст. 245].

Постановка завдання. Чіткий механізм проведення слідчих (розшукових) дій в ході кримінального провадження дає підстави не сумніватись у їх достовірності під час остаточної оцінки зібраних доказів судом і є запорукою винесення законного рішення за фактом провадження.

Завданнями статті є аналіз чинного законодавства і вибір оптимальної форми дії під час реалізації завдань кримінального провадження в ході проведення слідчих (розшукових) дій, а саме збирання і здобування доказів. Серед таких джерел доказів $є$ призначення судових експертиз на підставі отриманих зразків. Саме поняття біологічних зразків у вітчизняному законодавстві відсутне, тому необхідні спроби визначення як поняття, так і механізму опрацювання біологічних зразків в процесі їх вилучення у примусовий спосіб.

Це питання неодноразово поставало перед процесуалістами-науковцями, такими як А.І. Адоєвська, В.В. Войченко, О.В. Лускатовим, І.В. Пиріг, В.М. Тертишником, А.В. Шульженко, М.Г. Щербаковським та іншими, але до кінця так і не було вирішене, тому що донині відсутній чіткий механізм відібрання зразків для подальшого призначення $\mathrm{i}$ проведення експертизи, а також не визначена чітка роль прокурора в процесі примусового відібрання біологічних зразків.

Зазначене питання є важливим під кутом зору практичної реалізації завдань Кримінального процесуального законодавства, відповідно до засад якого зміст кримінального провадження повинен відповідати верховенству права, законності та іншим важливим умовам $[1$, ст. 7].

Результати дослідження. Отримання зразків для експертизи у добровільному порядку проблем не створює, тому що у разі добровільної особи сам процес не має ускладнень. Тим більше, якщо проведення експертизи доручено судом, суд без сторонньої допомоги має діяти на власний розсуд або складає доручення про це залученому до провадження спеціалісту.

У ч.1 ст. 245 зазначається, що навіть сторона захисту може відбирати зразки за необхідністю, вже долучаючи їх до клопотання про проведення експертизи. Слід зауважити, що

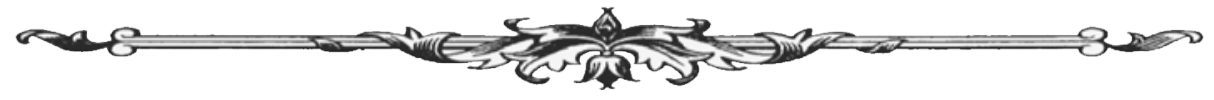


такий відбір має здійснюватись не захисником, не підозрюваним, не потерпілим або його представником, а спеціалістом у присутності понятих. Законодавством визначено відбір як процесуальну дію, а кожна процесуальна дія повинна знаходити своє відображення у протокольній формі.

Захисник має право брати участь брати участь у процесуальних діях, але не має право самостійно їх проводити [1, ст. 46 ], тому і не може самостійно вилучати зразки, а лише має право бути присутнім під час цього.

Підозрюваний має право збирати докази відповідно до ст. 42 ч.8 КПК, але біологічні або інші зразки доказами не є. Також він має заявляти клопотання про проведення процесуальних дій відповідно до ч. 12 цієї ж статті. У правах ані підозрюваного, ані обвинуваченого не зазначене право на відмову проведення слідчої дії, лише право відмовитись відповідати на запитання і не говорити нічого 3 приводу підозри [1, ст. 42]. Але це стосується відбору зразків взагалі, тому що такий відбір не пов'язаний із даванням показань і свідченнями проти себе. Однак, яким чином підозрюваний або обвинувачений може самостійно надати зразки до клопотання про призначення експертизи, законом не прописано. Виходячи 3 аналогії, процесуальна дія теж повинна проводитись стороною обвинувачення - слідчим або прокурором із залученням спеціаліста у присутності двох понятих.

Потерпілий відповідно до ст. 56 ч. 3 КПК України має право подавати докази, але зразки, як уже було зазначено, доказами не виступають. Представник потерпілого користується процесуальними правами потерпілого відповідно до положень ст. 58 ч. 4 КПК України.

На відміну від добровільного відбирання зразків, примусове може тягнути за собою низку негативних наслідків через те, що механізм такого відбору в кодексі не прописаний. Жоден коментар не розписує детального механізму самого примусового відбору, не описуються види опору підозрюваного, якщо він відмовляється від надання таких зразків, не зазначається чіткий алгоритм слідчого і прокурора під час проведення такого примусового відбору.

Тому потрібно підсумувати наведені дані, зазначивши при цьому, що добровільне відбирання зразків для проведення експертизи здійснюється як процесуальна дія, результати якої оформлюються у протокольній формі слідчим (або прокурором). До участі в дії може бути залучено спеціаліста, понятих, захисника. Присутність інших учасників здійснюється за їх клопотанням і його задоволенням.

Порядок відібрання зразків 3 речей і документів зумовлюється положеннями про тимчасовий доступ до речей і документів відповідно до ст. ст. 160-166 КПК України. Відповідно до нього слідчий суддя у відповідь на клопотання виносить рішення (ухвалу) про вилучення, фактичну виїмку під час такого тимчасового доступу. Невиконання ухвали про тимчасовий доступ дає підстави для винесення ухвали про проведення обшуку. Саме ж проведення обшуку здійснюється за участю особи, за клопотанням якої надано дозвіл на його проведення (ст. 166 ч. 2 КПК України). Тобто під час обшуку можливе вилучення предметів, які містять на собі зразки, необхідні для проведення експертизи.

Тому ми маємо три варіанти дій у разі примусового відбору зразків:

- безпосередньо примусовий відбір, здійснюваний прокурором або слідчим за допомогою спеціаліста в присутності захисника підозрюваного (обвинуваченого, підсудного), який може здійснюватись як прямо, так і під час освідування.

- тимчасовий доступ до речей, які мають на собі сліди, що можуть бути досліджені судовими експертами в процесі експертного дослідження, і цей доступ має добровільний характер.

- проведення обшуку за ухвалою слідчого судді, в процесі якого можуть бути виявлені речі або предмети з необхідними для дослідження зразками.

Про відбирання біологічних зразків зазначається в ч. 3 ст. 241 КПК України, яка відсилає до порядку проведення освідування. Тобто зразки біологічного походження вилучаються у такий спосіб, як і під час освідування. Особа, яка освідується у примусовому порядку, отримує на руки копію протоколу про проведення освідування. Саме ж освідування здійснюється на підставі постанови прокурора та, за необхідністю, з участю судово-медичного

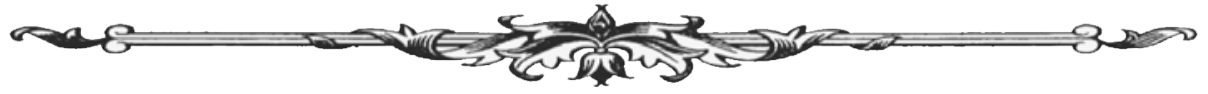


експерта або лікаря. В цьому разі роль прокурора чітко визначена як ініціатора, відповідального за прийняте про освідування рішення.

Якщо ж особа відмовляється добровільно надати біологічні зразки, сторона кримінального провадження виступає 3 клопотанням до суду (слідчий, прокурор) мають право, несуть обов’язок здійснити відбирання біологічних зразків примусово. Ст.ст. 160-166 КПК України, до яких відсилає законодавець, регулює, як уже було зазначено, вилучення саме предметів, які можуть містити на собі сліди біологічних виділень людини, але що це за виділення і на яких речах вони можуть міститись, жоден нормативний документ, доповнюючий процесуальний кодекс, не містить.

Потрібно визначитись із поняттям зразків і біологічних зразків. Ні КПК України, ні інші нормативні акти цих визначень не мають, але вони вкрай важливі для реалізації завдань правосуддя в частині проведення експертиз.

Зразок є багатозначним терміном, але з кримінальним процесом пов'язане значення частини чогось, з якої можна скласти уявлення про ціле - «типове втілення властивості» [2, с. 698 ]. Зразки відбираються для процесу ідентифікації у разі проведення експертного дослідження.

В «Теорії доказового права» сліди злочину співвідносяться з речовими доказами: сліди злочину поділяються та три великі групи: сліди-предмети; сліди-речовини (залишки-речовини); сліди-відображення. Сліди є частиною об'єктів матеріального світу - потенційних речових доказів [3, с. 122].

B.M. Тертишник під зразками для експертного дослідження розуміє «речовини або предмети», а також їх матеріально-фіксовані відображення, що характеризують властивості певних об'єктів чи осіб, які підлягають експертному дослідженню (відбитки пальців рук, взуття, зліпки зубів, проби крові, слини, зразку почерку, шрифту друкарської машинки тощо)» [4, с. 408].

B.I. Гончаренко визначає лише поняття об’єктів експертизи - «матеріальних носіїв доказової інформації, зібрані і надані експертові слідчим або судом» [5, с. 57].

Порівняльні зразки визначаються як «матеріальні джерела інформації, які відображують якості об' єктів, що перевіряються, або самі ці об'єкти», і поділяються на 4 види:

1. Зразки, які відображають зовнішню будову об'єкта (кліше печатки, штампа, знаряддя травми тощо).

2. Зразки, які відображають склад і структуру об’єкта (зразки дробу, проби грунту тощо).

3. Зразки, які відображають функційні особливості об'єкта або механізму утворення слідів (професійні навички людини, зразки почерку, письмового і усного мовлення тощо).

4. Комплексні зразки, які одночасно відображають декілька характеристик об'єкта-оригінала (зразок тексту на матричному принтері тощо).

Але в класифікацію не входять ні біологічні зразки, ні зразки, які походять від людини і не є біологічними виділеннями [ 6, с.108-109].

Автори методичних рекомендацій «Примусовий відбір зразків у особи для проведення експертизи» надають декілька визначень. Так, наприклад, до зразків біоматеріалу належать кров, сеча, жовч, слина, м'язи, частини внутрішніх органів, кістки, мазки з вмістом вагіни, ротової порожнини; зразки біологічного середовища - слина, сеча, змиви 3 поверхні губ, шкірного покриву обличчя і рук, кров [7, с.14].

Враховуючи приведену інформацію, на наш погляд, біологічними зразками слід вважати продукти виділення людини, серед яких слина, кров, сперма, вагінальні виділення, потожирова речовина, волосся, відлущення шкірного покриву. Все інше слід вважати об'єктами біологічного походження.

У процесі оформлення процесуальних документів про відібрання біологічних зразків прокурором повинно визначатись, який саме вид біологічного зразка або зразків підлягає вилученню, в який спосіб, коли, де і в присутності кого з учасників кримінального провадження.

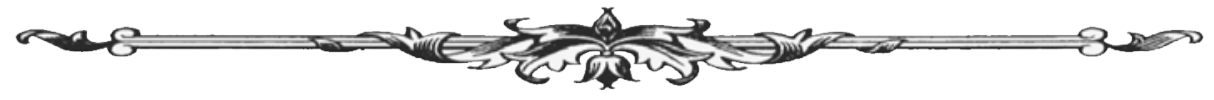


Серед діючих слідчих підрозділів не є популярним клопотання про примусове відібрання біологічних зразків, тому що питання примусу і його визначення є спірним. Під примусом можуть приховуватись ознаки катування, тортур, мучіння, заподіяння побоїв, а також інших насильницьких дій.

Кримінальний процесуальний кодекс не містить визначення примусу, але вживається це поняття у складі понять «примусові заходи медичного характеру», «примусові заходи виховного характеру» тощо. У цих визначеннях акцент робиться на забезпечення інтересів особи, до якої ці заходи застосовуються. В понятті «примусові заходи» теж є примус, який пов’язаний $з$ певними обмеженнями прав і свобод.

На наш погляд, примус - це здійснення процесуальних дій, заходів всупереч бажанню, волі, з метою доведення вини або невинуватості, з метою запобігання порушень прав людини через притягнення невинуватої особи до кримінальної відповідальності або непритягнення до відповідальності винуватої особи.

Тепер слід розглянути, яким чином відбувається непогодження підозрюваного з добровільним наданням біологічних зразків. Це непогодження може бути висловлено в усній або письмовий формі, може бути у вигляді ухилення від проведення процесуальних дій. Інші форми, на нашу думку, неможливі. Непогодження може бути пов'язане $з$ приховуванням інформації, яка доводить вчинення злочину саме цією особою, і тому непрямо може тільки підтверджувати цей факт.

Тому вважаємо, що незгода надати біологічні зразки добровільно може бути непрямим доказом саме винності і свідчити про бажання уникнути покарання.

У тому разі, якщо підозрюваний (обвинувачений, підсудний) активно, фізично протидіє виконанню ухвали суду про примусове відібрання зразків, прокурору, на нашу думку, слід ініціювати долучення до проведення процесуальної дії не тільки захисника зі сторони захисту, а й спеціаліста, який би дав оцінку психологічного або психічного стану особи, у якої мають бути вилучені зразки.

Так, А.В. Шульженко наголошує на тому, що активний опір проведенню необхідних слідчих (розшукових) дій з боку підозрюваного може викликати сумнів в адекватності особи, що є підставою для запрошення психолога або психіатра для проведення слідчої дії та оцінки поведінки особи, у якої примусово вилучаються зразки [ 8, с.130].

На нашу думку, прояви неадекватної поведінки можуть бути підставою для негайного призначення судово-психіатричної експертизи, що прямо співвідноситься 3 положеннями Кримінального процесуального кодексу.

Про примусові дії з боку співробітників правоохоронних органів, які мають злочинний, насильницький характер, можуть свідчити результати освідування, проведення судово-медичної експертизи, допит свідків тощо.

Висновки. Кожне кримінальне провадження визначається своїм унікальним складом обставин і наявних доказів. Призначення судових експертиз здійснюється на підставі наявних фактичних обставин і вилучених зразків, речей, документів тощо. Для організації примусового вилучення зразків на підставі ухвали слідчого судді прокурору належить провідна роль, за якою він чітко повинен вказати на обставини і механізм такого вилучення, склад присутніх. Оцінюючи ситуацію, їі складність, прокурор може обрати інші варіанти дій, якими можуть бути освідування, тимчасовий доступ до речей або ж проведення обшуку.

Список використаних джерел:

1. Кримінальний процесуальний кодекс України. URL: ttp://zakon5.rada.gov.ua/laws/ show/4651-17 (дата звернення: 01.11.2019).

2. Словник Української мови. Академічний тлумачний словник (1970-1980) Словник української мови: в 11 томах. Том 3, 1972. C. 698. URL: http://sum.in.ua/s/zrazok (дата звернення: 01.11.2019).

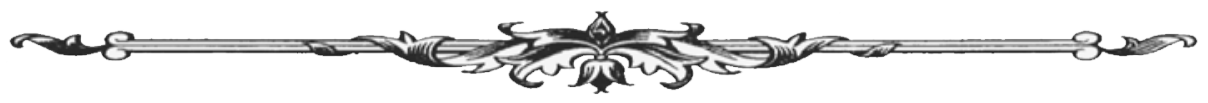


3. Теорія доказів: підручник для слухачів магістратури юридичних вузів / Антонов К.В., Сачко О.В., Тертишник В.М., Уваров В.Г. / За заг. ред. д. ю. н., професора В.М. Тертишника. Київ : Алерта, 2015. 294 с.

4. Тертишник В.М. Науково-практичний коментар Кримінально-процесуального кодексу України. Видання 12-те доповн. і перероб. Київ : Алерта, 2016.810 с.

5. Експертизи у судовій практиці. / За заг. ред. В.Г. Гончаренка. Київ : Юрінком Інтер, 2004. 388 c.

6. Щербаковский М.Г. Судебные экспертизы: назначение, производство, использование : учебно-практическое пособие. Харьков : Эспада, 2005. 544 с.

7. Примусовий відбір зразків у особи для проведення експертизи. Методичні рекомендації для практичних підрозділів. ДДУВС МВС України. Дніпро : Дніпропетровський державний університет внутрішніх справ, 2017. 36 с.

8. Шульженко А.В. Примусовий відбір зразків для експертизи. Актуальні проблеми вітчизняної юриспрудениіï. 2018, № 2, випуск 2. С. 127-130.

\section{HOP B. T.,}

доктор юридичних наук, академік Національної академії правових наук України, професор кафедри кримінального процесу і криміналістики (Львівський національний університет імені Івана Франка)

\section{ШЕВЧУК М. І.,} кандидат юридичних наук, доцент кафедри кримінального процесу i криміналістики

(Львівський національний університет імені Івана Франка)

\section{УДК [343.13:341.645] $(477+4)$ \\ DOI https://doi.org/10.32842/2078-3736-2019-6-2-28}

\section{ОБГРУНТОВАНА ПІДОЗРА ЯК ПІДСТАВА ДЛЯ ОБРАННЯ ЗАПОБІЖНОГО ЗАХОДУ ТА ПРОДОВЖЕННЯ ЙОГО СТРОКІВ: ПРАКТИКА ЄВРОПЕЙСЬКОГО СУДУ $З$ ПРАВ ЛЮДИНИ ТА УКРӒ̈НСЫКІ РЕАЛІЇ}

Стаття присвячена аналізу теоретичних і практичних проблем, які стосуються обгрунтованої підозри як однієї з підстав для обрання запобіжних заходів та їх продовження. У ній проаналізовані запропоновані вченими різноманітні підходи щодо підстав для обрання запобіжних заходів. На підставі аналізу положень чинного Кримінального процесуального кодексу України, міжнародних стандартів щодо захисту прав людини, закріплених у ст. 5 Конвенції про захист прав людини та основоположних свобод, правових позицій Європейського суду з прав людини визначено підстави для обрання запобіжних заходів. Також проаналізовано правові позиції Європейського суду з прав людини, норми Кримінального процесуального кодексу України та наукові позиції вітчизняних

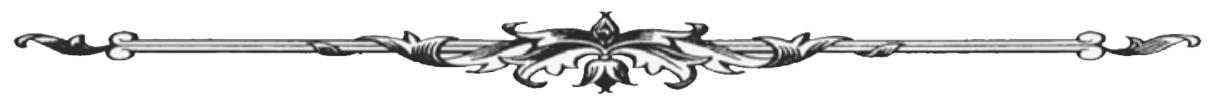

